\title{
A BEAUTIFUL CRANE-FLY FROM SIAM
}

\author{
By T. D. A. Cockerell
}

I have lately received from Dr. and Mrs. James W. McKean along with many other insects, an extremely handsome Tipula collected at Chiengmai, Siam, June 28, 1928. The insect was so remarkable that I looked it up in the literature, and decided that it was allied to T. pedata Wied., but new.

Tipula (Tipulodina) mckeani n. sp.

\%. Length $28 \mathrm{~mm}$., wing $18 \mathrm{~mm}$.; hind tibia 20.2, hind tarsus 21.5, hind femur 19, ovipositor 1, antennæ about 3, proboscis $1.5 \mathrm{~mm}$.

Antennal scape white at base, more than apical half brown; flagellar joints brown, with somewhat swollen black base, which carries rather long hairs. Facial and frontal regions whitish, with a dusky stripe in middle of front; sides of snout ochreous, posterior part of head dark brown. Thorax dorsally pale brownish grey, a narrow dark brown stripe anteriorly, and the lateral areas broadly pallid, the pleural region whitish; halteres light brown. Wings clear hyaline, marked with dark brown in the manner of $T$. pedata Wied, except that there is no clear costoapical spot, though the color in this region is paler, and the cell R5 is clear except at extreme base; there is a small suffused brown spot on the lower margin of cell $M$, just about the middle. Abdomen dark brown above, beneath pale and flavescent, segments more or less pallid along apical margins. Femora broad, with blackened apex, the anterior pair broadly dull luteous subapically. Anterior and middle tibiæ black, with a portion $4.5 \mathrm{~mm}$. long and about $3 \mathrm{~mm}$. from apex, creamy white; their tarsi with about the basal $7 \mathrm{~mm}$. black and the rest creamy white; hind tibiæ with an additional white ring, 
about $3.5 \mathrm{~mm}$. long, near the base, and only about $5 \mathrm{~mm}$. of their tarsi black.

Type in the collection of Dr. C. P. Alexander who confirms the species as new, and cites the following as the closest allied: T. pedata Wied., T. fuscitarsis Edw., T. tinctipes Edw., T. micrantha Alex., T. scimitar Alex., T. venusta Walk. From all of these it differs in the combination of leg pattern and coloration of body and wings.

\section{BOOK NOTICES}

A Handbook of the Dragonflies of North America. By J. G. Needham and H. B. Heywood. vi +368 pp., with many figures and diagrams. Charles Thomas, Springfield, Illinois. $\$ 7.00$.

The scattered literature relating to North American Odonata has been gathered together, digested and presented with a large amount of new material in the present book. The introduction of about fifty pages includes a short account of structure and habits and the remainder is a very complete taxonomic treatment, including keys, of the adults and nymphs so far as the latter are known. This is a "handbook" in the full sense of the word, and with its list of literature should serve as a complete guide to the field with which it deals.

C. T. BRUES.

The Problems of Applied Entomology. By R. A. Wardle. vii +587 pp., 31 figures. McGraw-Hill Book Co., New York. $\$ 6.00$.

After the extensive series of text books on insects that have been published during the past few decades, it would seem that no actually new and unique treatment of any extensive entomological field could be expected. Professor Wardle has shown that such is not the case, and has worked 

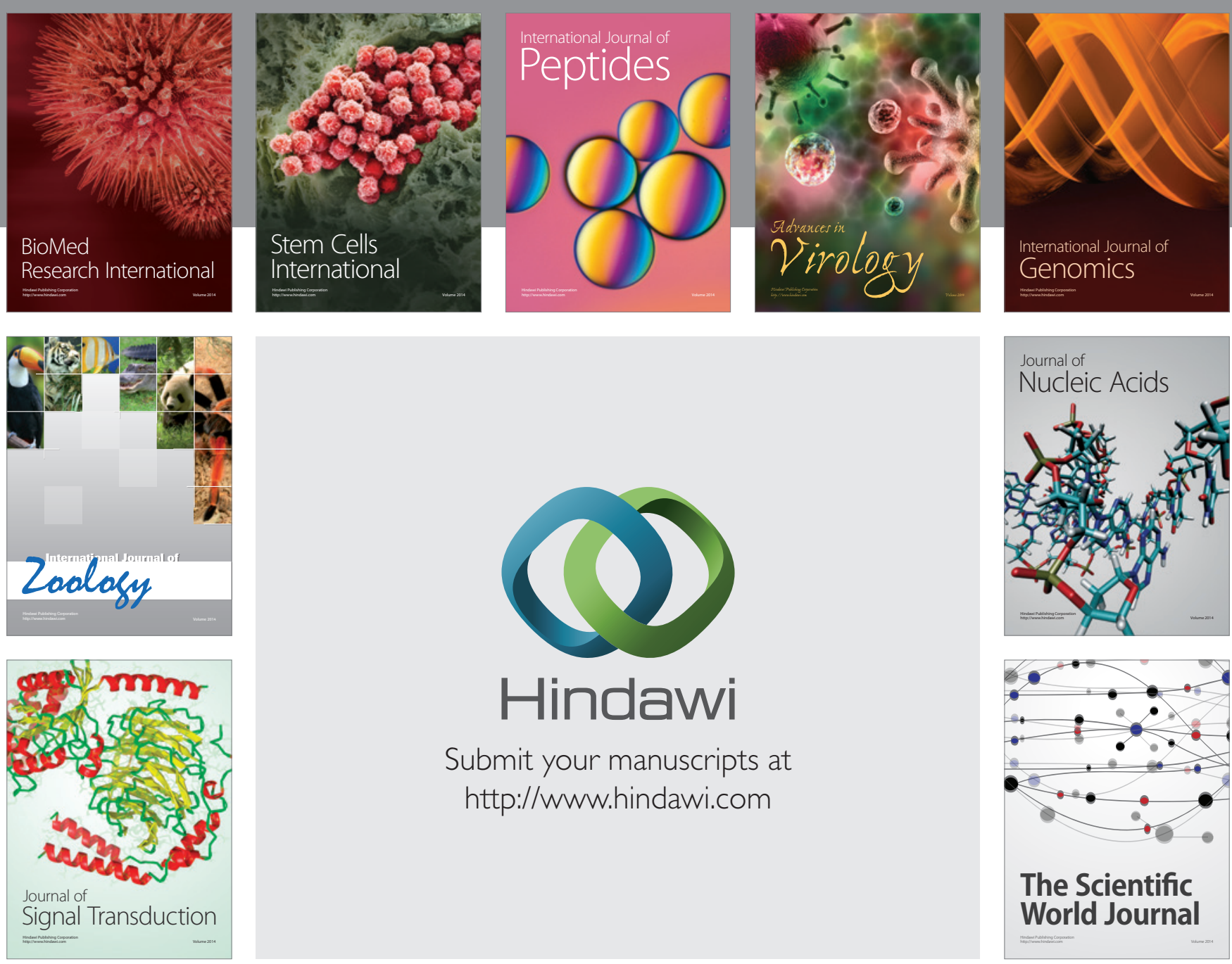

Submit your manuscripts at

http://www.hindawi.com
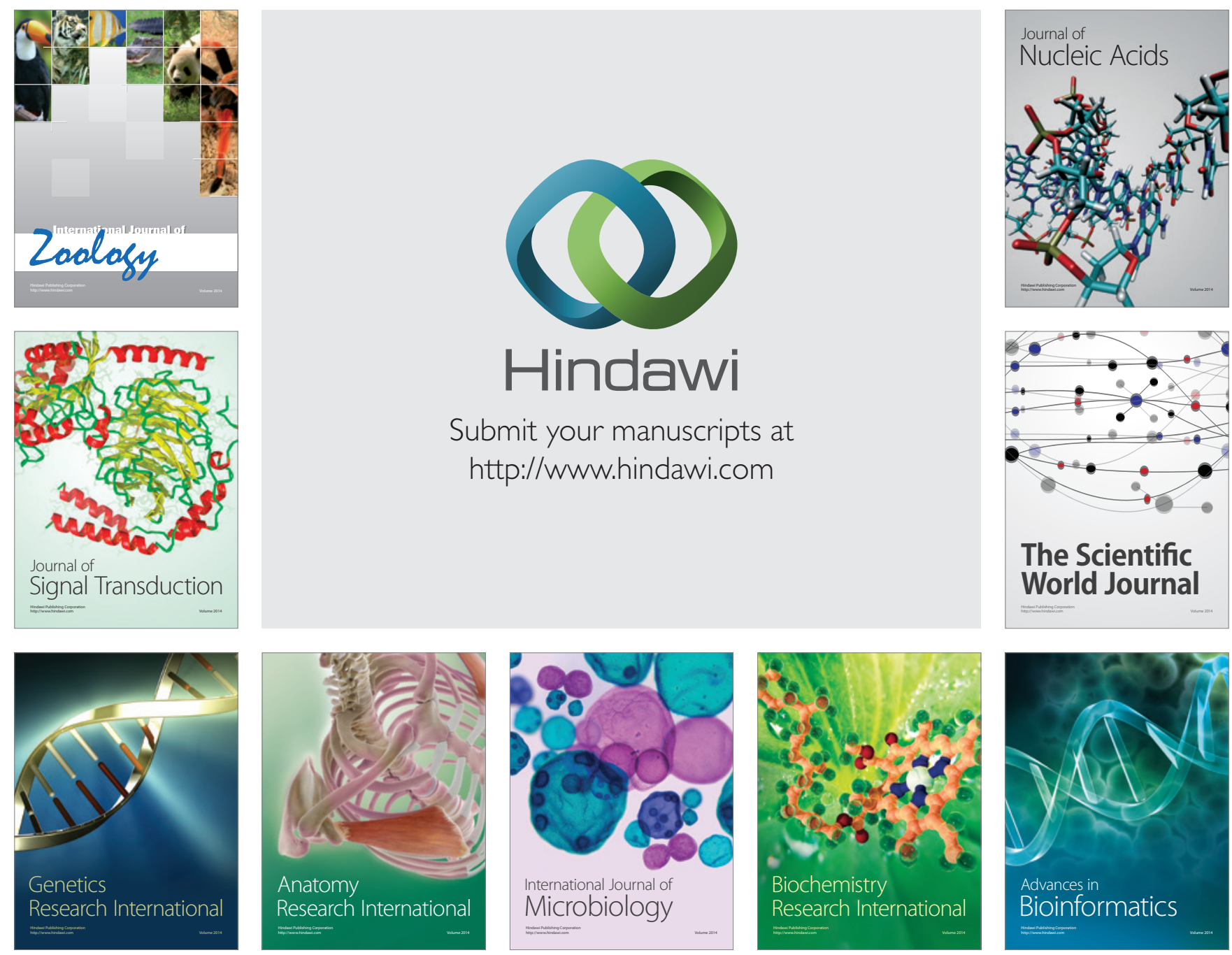

The Scientific World Journal
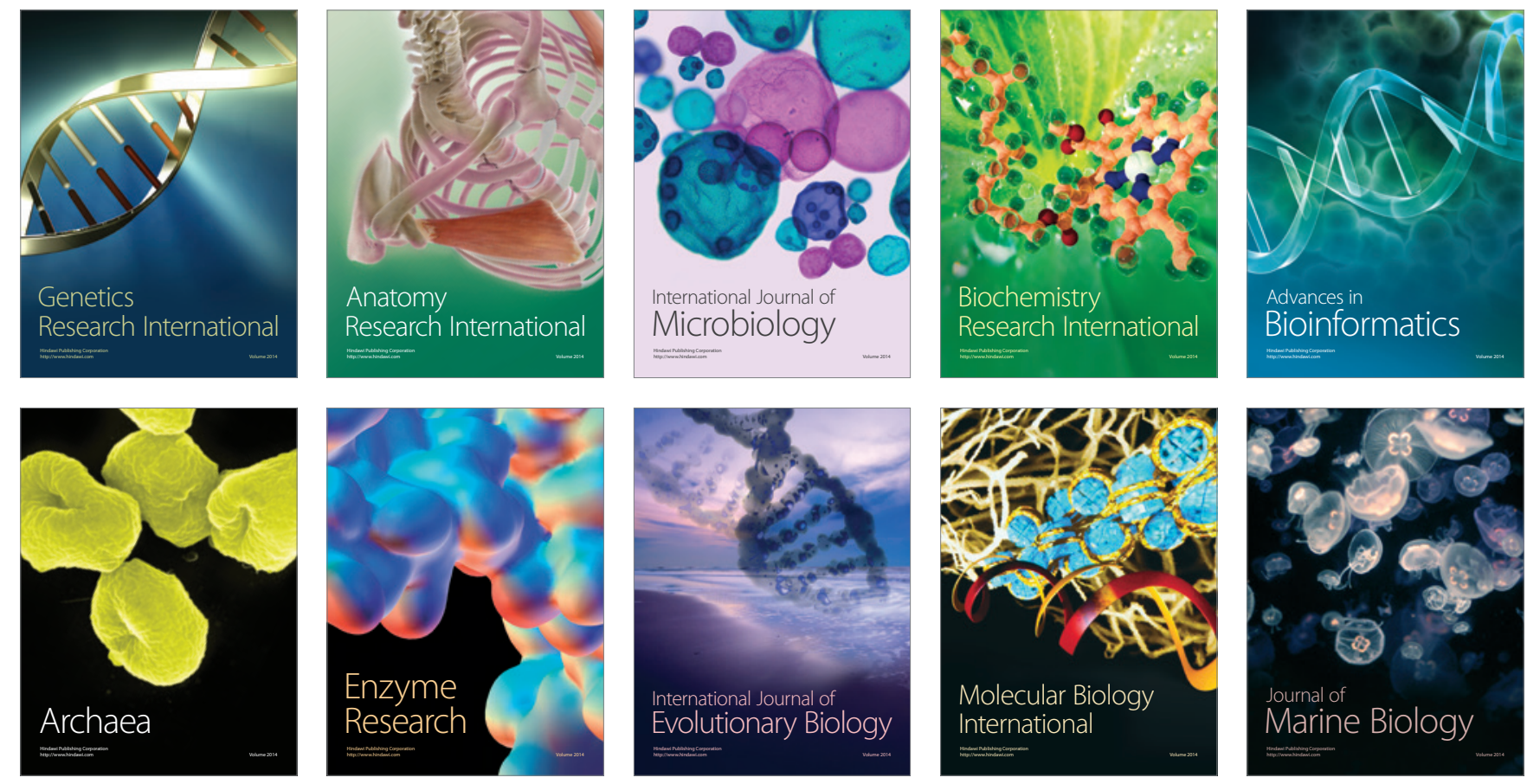